\title{
A critical evaluation of coastal erosion in Rio Grande do Sul, Southern Brazil
}

\author{
SÉRGIO R. DILLENBURG ${ }^{1}$, LUCIANA S. ESTEVES ${ }^{2}$ and LUIZ J. TOMAZELLI ${ }^{1}$ \\ ${ }^{1}$ Universidade Federal do Rio Grande do Sul, Instituto de Geociências \\ Centro de Estudos de Geologia Costeira e Oceânica, Cx. Postal 15001, 91509-900 Porto Alegre, RS, Brasil \\ ${ }^{2}$ Fundação Universidade Federal do Rio Grande, Departamento de Geociências \\ Laboratório de Oceanografia Geológica, Cx. Postal 474, 96201-900 Rio Grande, RS, Brasil
}

Manuscript received on September 17, 2003; accepted for publication on May 26, 2004;

presented by LAURO NARDI

\begin{abstract}
Evidences of coastal erosion in Rio Grande do Sul have been obtained by three methods: (a) analysis of the long-term morphodynamics and stratigraphy of coastal barriers, (b) annual shoreline mapping using the Differential Global Positioning System (DGPS), and (c) local beach profile measurements. The first method reflects coastal erosion as continuity of the geological evolution in the last $5 \mathrm{ka}$, taking place mainly along the southern half of gentle coastal projections. The second method represents a shorter temporal scale and indicates that approximately $80 \%$ of the coast is eroding. Beach profiling has been measured in very few places that are distant from each other since the early 1990s; consequently, their results reflect local and very short time shoreline behavior. A critical evaluation of published data addressing coastal erosion in Rio Grande do Sul strongly suggests that short and long term negative balance on the sediment budget is the main cause of erosion along this coastline.
\end{abstract}

Key words: coastal evolution, Quaternary, shoreline changes, coastal barriers, sediment budget.

\section{INTRODUCTION}

Coastal erosion is a process occurring worldwide, especially on low-lying coastal plains (Bird 1985). Many studies have discussed the causes of erosion, in the short and long temporal and spatial scales. Erosion usually results from the combination of multiple factors interacting along the coast. However, regardless of the time and spatial scale, coastal erosion is essentially a consequence of sea level rise and/or negative sediment budget.

Rio Grande do Sul (RS) is the southernmost state of Brazil (Fig. 1). Except for the northernmost

Correspondence to: Sergio R. Dillenburg

E-mail: sergio.dillenburg@ufrgs.br
$136 \mathrm{~km}$, its 620-km long shoreline is mainly undeveloped and visited mostly in the summer months when calm and warm weather prevails (Esteves et al. 2003b). Probably, this is the reason why coastal studies have not attracted the attention of community, government, or researchers until recently. Only in the late 1980s, studies started to focus on coastal processes, including the first published note addressing beach erosion in RS (Tomazelli and Villwock 1989). Since then, coastal erosion in RS has been discussed on several studies, mainly regarding its natural and human-induced causes in the long(e.g. Tomazelli et al. 1998, Tomazelli and Dillenburg 1998, Dillenburg et al. 2000) and short-term (e.g. Calliari et al. 1998a,b, Esteves et al. 2000, 
Toldo et al. 1999). Recently, attempts have been made to critically evaluate published data on erosion along the RS coast (Esteves et al. 2002).

The increasing interest on coastal processes and shoreline changes reflects the intensification of coastal occupation and beach use, as well as the growing economic importance of beach-related tourism. This paper aims to critically evaluate the state-of-the-art in the knowledge of coastal erosion in RS almost 15 years after the first studies about this theme.

\section{REGIONAL SETTING}

The southern Brazil continental margin is a rifted plate boundary formed in Early Cretaceous times. In the vicinity of Rio Grande do $\operatorname{Sul}\left(29^{\circ}\right.$ to $34^{\circ}$ south latitudes), deposition of a large amount of post-rift, mainly clastic sediments, produced a wide (100 to $200 \mathrm{~km}$ ), shallow (100 to $140 \mathrm{~m}$ ), and gently sloping $\left(0.03^{\circ}\right.$ to $\left.0.08^{\circ}\right)$ continental shelf. Seismic records of the upper slope reveal a sedimentary thickness of at least $10 \mathrm{~km}$ (Fontana 1990).

Rio Grande do Sul coastline is characterized by a $620-\mathrm{km}$ long and gently undulating barrier, generally oriented NE-SW, comprised essentially by exposed, fine sand, dissipative to intermediate beaches (Fig. 1). It is one of the longest sandy beaches of the world, presenting only two permanent discontinuities (Tramandaí and Patos lagoon inlets).

Climate is humid temperate with annual mean temperatures of $18^{\circ} \mathrm{C}$, presenting warm to hot temperatures in summer (mean of $26^{\circ} \mathrm{C}$ ) and cool temperatures in winter (mean of $12^{\circ} \mathrm{C}$ ). Rainfall is evenly distributed throughout the year, ranging from 1000 to $1500 \mathrm{~mm}$. The dominant northeast winds persistently blow along the RS coast, although southerly winds are the strongest and more frequent during the fall and winter seasons.

This is a microtidal coast with semidiurnal tides presenting a mean range of $0.5 \mathrm{~m}$. Thus, sediment transport and deposition along the open coast is primarily dominated by wave action. Although the most frequent waves are generated by local and usually long-lasting winds from the northeast, southerly waves associated to the formation of extra-tropical cyclones far away in the Mid-Atlantic are the strongest. The average significant wave height is $1.5 \mathrm{~m}$, measured at depths of about $15-20 \mathrm{~m}$ (Motta 1969). A net northward littoral drift is evident in coastal geomorphologic features (Tomazelli and Villwock 1992) and by field measurements (Toldo et al. 1993). At present, RS beaches receive very little sand from inland as most of the beadload carried through the drainage system is trapped in lagoons and other coastal plain environments (Tomazelli et al. 1998).

The post-glacial sea level history of the RS coast extends from about $17.5 \mathrm{ka} \mathrm{BP}$, when the sea was positioned at about -120 to $-130 \mathrm{~m}$ (Corrêa 1995). Since then, sea level rose at an average rate of $1.2 \mathrm{~cm} / \mathrm{yr}$ until $6.5 \mathrm{ka} \mathrm{BP}$, when it started to slow down (Fig. 2). There is no reliable data on sea level change from the Middle to Late Holocene along the RS coast. Sea level curves established for areas further north in Brazil indicate that sea level reached a few meters above its present level at the culmination of the Post-glacial Marine Transgression PMT (5 ka BP), followed thereafter by a slow sea level fall (Martin et al. 1979, Angulo and Lessa 1997) (Fig. 2). It is likely that the general shape of these sea level curves also apply to the northern sector of the Rio Grande do Sul coast (Dillenburg 1996), although peaks might have not reached the same level. The sea level curve presented by Martin et al. (1979) show a maximum of $+5 \mathrm{~m}$ for the coast of Bahia (NE Brazil). Angulo and Lessa (1997) suggest a maximum sea level around $+3.5 \mathrm{~m}$ in the states of São Paulo (SE Brazil) and Paraná (southern Brazil, north of RS). Finally, Angulo et al. (1999) show evidences of a maximum around $+2 \mathrm{~m}$ in the state of Santa Catarina, $100 \mathrm{~km}$ north of RS.

\section{QUATERNARY COASTAL EVOLUTION}

The geologic evolution of the RS coastal plain was described by Villwock et al. (1986) and detailed in 


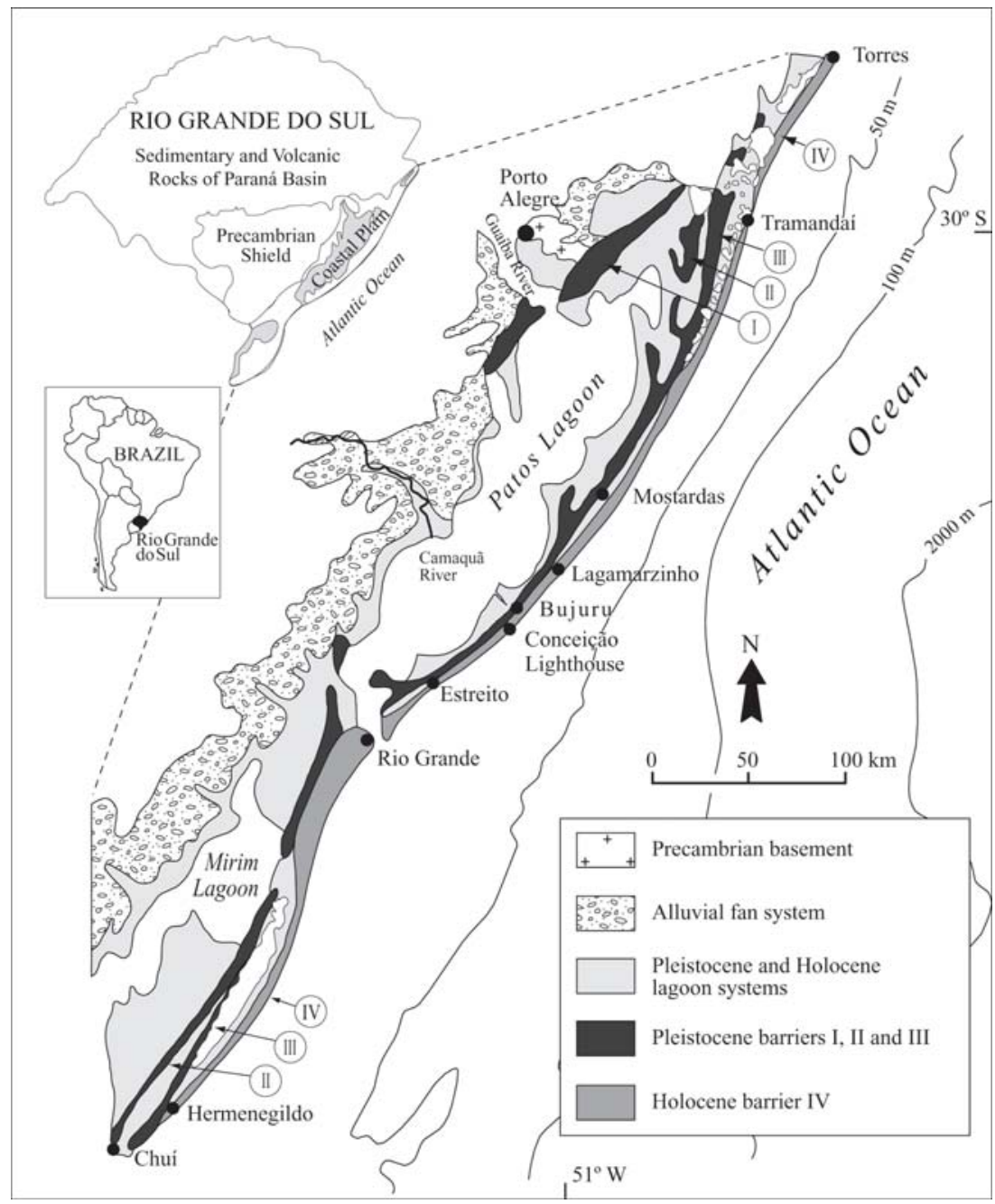

Fig. 1 - Location of the Rio Grande do Sul coastal plain showing its general geology (Modified from Tomazelli et al. 2000).

several following studies (i.e. Villwock and Tomazelli 1995, Tomazelli et al. 2000). This section summarizes the main points of the Quaternary coastal evolution, as it is a key-factor for the present shoreline configuration.

The coastal plain comprises two major depositional systems formed by sea level fluctuations in the Quaternary: the alluvial fan deposits that mark the western limit of the coastal plain and the barrierlagoon systems developed seawards (Tomazelli et al. 2000) (Fig. 1). The alluvial fan system consists in coarse-grained clastic deposits originated from gravity flows and accumulated at the base of the highlands. These deposits date probably from the Late Pliocene regression up to the Early Holocene. Deposits at the edge of coalescent fans were eroded by higher sea levels in the Pleistocene resulting in marine and lagoon terraces that are particularly well developed and preserved to the south.

Four barrier-lagoon depositional systems were identified in the RS coastal plain, each representing the sedimentary record of a marine transgression, three during the Pleistocene and one in the Holocene (Fig. 1). Each barrier represents the land- 


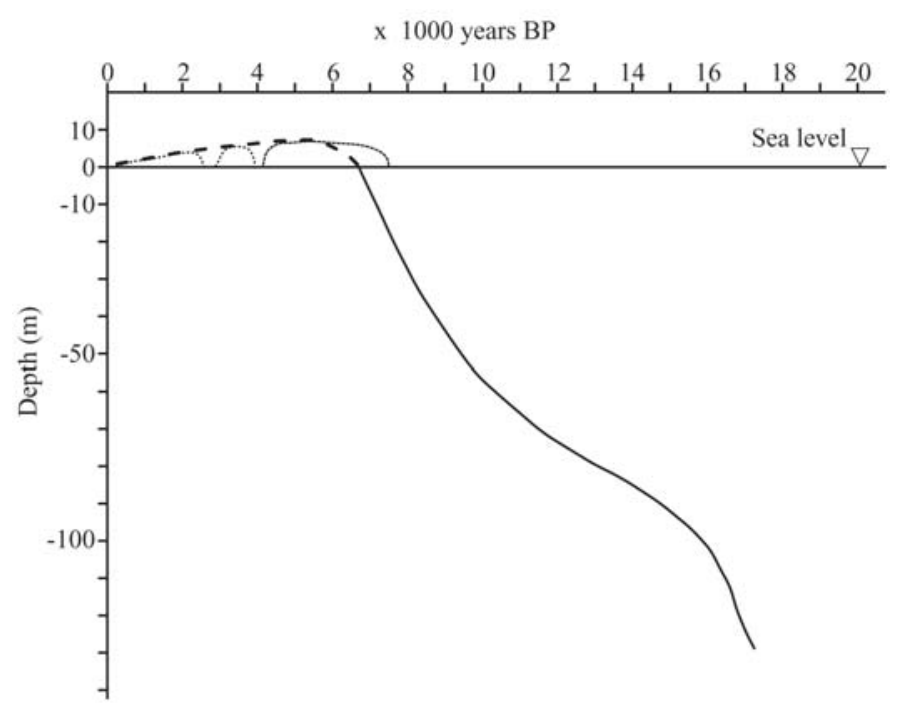

Fig. 2 - Holocene sea level curves for the east coast of Brazil. Solid curve after Corrêa (1995). Dotted curve after Martin et al. (1979). Dashed curve after Angulo and Lessa (1997).

ward limit of the respective maximum transgressive event (Villwock and Tomazelli 1995, Tomazelli et al. 2000). Villwock et al. (1986) named the four barrier-lagoon systems as Barrier I (the oldest) to IV (the youngest). Absolute ages of the Pleistocene barriers are still unknown (Tomazelli et al. 2000). An attempt to correlate the last major peaks of the oxygen isotopic record and barrier formation suggests that they were probably formed in the last $400 \mathrm{ka}$ (Villwock and Tomazelli 1995). Barrier I, II, and III correlate with oxygen isotopic stage 11 (about $400 \mathrm{ka}$ ), stage 9 (325 ka), and sub-stage 5e (approximately $120 \mathrm{ka}$ ), respectively. Barrier IV was formed in the Holocene and corresponds to oxygen isotopic stage 1 . About $18 \mathrm{ka}$ ago, sea level was near the present shelf break and rose steadily up to 2-4 $\mathrm{m}$ above the present level at the maximum of the last transgression (5 ka). Recent ${ }^{14} \mathrm{C}$ data indicate that Barrier IV was formed between 6.44 and $4.65 \mathrm{ka}$ in the northern coast of Rio Grande do Sul (Dillenburg et al. 2004b). After that, a slow sea level fall (rates ranging from 0.4 to $0.8 \mathrm{~mm} /$ year) favored progradation of Barrier IV in the smooth embayments in between Torres and Tramandaí and in Rio Grande, and retreat along the coastal projections (Dillenburg et al. 2000).

\section{EVIDENCES OF COASTAL EROSION}

Analysis of the long-term morphodynamics and stratigraphy of coastal barriers provided the most conspicuous evidence of erosion along the RS coast, the exposure of lagoonal muds and peat at the present backshore in Hermenegildo and Bujuru (Fig. 3a and b). The exhumation of relict muds occurs continuously along $15 \mathrm{~km}$ alongshore in Hermenegildo and $60 \mathrm{~km}$ in the area Bujuru-Conceição lighthouse. In both locations muds are exposed along the southern half of the gentle coastal projections. Lagoonal muds were dated $\left({ }^{14} \mathrm{C}\right)$ on $4.33 \mathrm{ka}$ and $3.49 \mathrm{ka}$ at Hermenegildo and Bujuru, respectively (Tomazelli et al. 1998). The formation of such deposits implies that, at that time, there was a coastal barrier seaward of those places. Thus, sometime later, the barrier started a landward translation to reach its present position.

Foredunes in front of the Conceição lighthouse have retreated at an average rate of $2.5 \mathrm{~m} / \mathrm{yr}$ in the period 1975-1995 (Tomazelli et al. 1998). As a con- 


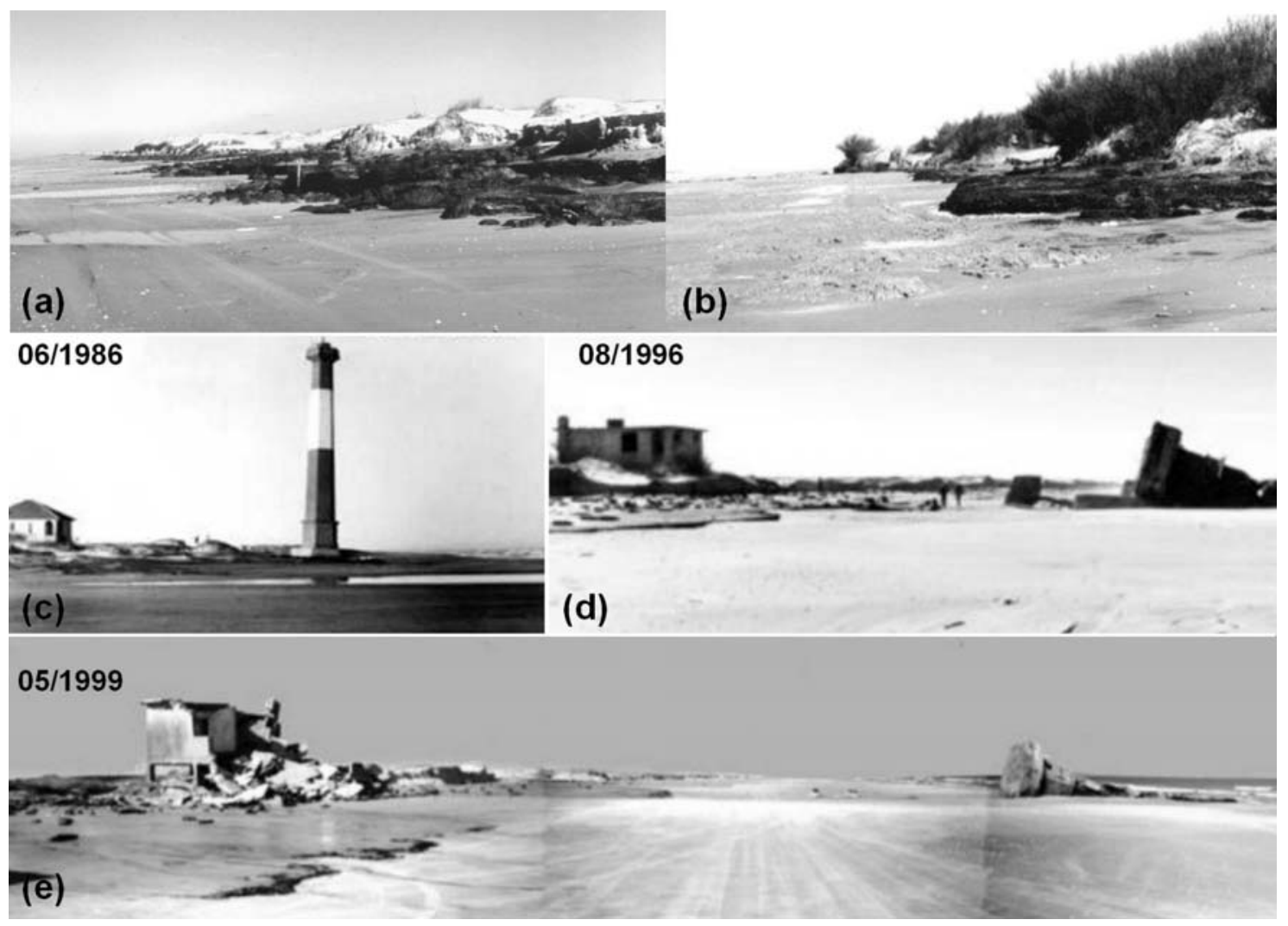

Fig. 3 - Long-term evidences of erosion along the coast of Rio Grande do Sul. Lagoonal mud and peat exposed in the backshore of Hermenegildo (a) and Bujuru (b). Conceição Lighthouse in 1986 (c), in 1996 (fallen after a storm surge in 1993) (d), and in 1999 (e). Shoreline has retreated in a rate of $2.5 \mathrm{~m} /$ year from 1975 to 1995.

sequence of such intense erosion, the lighthouse felt under wave attack during a storm in 1993 (Fig. 3c, $\mathrm{d}$ and e). The analysis of beach profiles from 1996 to 1999 shows an average retreat rate of $3.6 \mathrm{~m} / \mathrm{yr}$ for the same area and $1 \mathrm{~m} / \mathrm{yr}$ for Lagamarzinho beach, about $70 \mathrm{~km}$ north of Conceição lighthouse (Barletta and Calliari 2003). Unfortunately, beach profiles have been monitored locally and for less than about a decade, at best. Consequently, their results reflect local and short-time shoreline behavior only.

Since 1997, the Rio Grande do Sul shoreline has been mapped in a yearly basis using the kinematic Differential Global Positioning System (DGPS) method (Morton et al. 1993, Toldo et al. 1999, Esteves et al. 2003c). A DGPS is installed in a vehicle moving along the water line in an average speed of about $50 \mathrm{~km} / \mathrm{h}$ to register positions every $3 \mathrm{~s}$. DGPS errors are less than $1 \mathrm{~m}$ for the method used. In an attempt to determine longerterm changes, DGPS lines have been compared to a digitized shoreline of 1975 obtained from topographic maps printed in a scale of 1:50,000 (Toldo et al. 1999). Although the scale of the base maps is inadequate to this type of study, it was the best available source for a statewide analysis in a time period of more than a couple of years. A large error range was used to qualitatively classify shore segments in three classes: eroded, stable, and accreted. The comparative analysis of the 1975 digitized shoreline and the 2000 DGPS line indicates that approximately $81 \%$ of the beaches are eroding, $12 \%$ are stable, and the remaining $7 \%$ are accreting (Esteves et al. 2002). Similarly, Toldo et al. (1999) identified erosion along $84 \%$ of the shoreline and accretion 
along about $8 \%$ for the $1975-1997$ interval. Obviously, results will be more reliable after decades of continued shoreline mapping from which long-term trends and erosion rates can be determined.

\section{CAUSES OF EROSION}

Although evidences of erosion are clear, its causes are still in debate. About 15 years ago, the first paper addressing coastal erosion in RS suggested that the key factor leading to erosion was a contemporaneous rise in sea level (Tomazelli and Villwock 1989). Analysis of recent studies indicate that negative balances on the sediment budget may play a major role on coastal erosion.

Following, the discussion will focus on the two main causes of coastal erosion: sea level rise and a negative balance on sediment budget. Sea level rise will be considered as a factor producing coastal erosion in a long-term when rates of sea level exceeds rates of sediment input. Sediment budget will be discussed on both short and long term scales.

\section{Relative Sea level Rise}

A sea level rise is an outstanding cause of erosion and an important factor on coastal evolution. Marine transgression occurs when the rate of sea level rise exceeds the rates of sediment input to the coast. Such conditions typically form transgressive barriers on wave-dominated coasts (e.g. Roy et al. 1994). A barrier translation under a rising sea level leads to the overlying of lagoonal/estuarine fine sediments by barrier sands, usually washover deposits.

Tomazelli and Villwock (1989) evocated that a contemporaneous sea level rise is eroding the coastline of Rio Grande do Sul based on evidences such as: (a) the exhumation of lagoonal muds at Hermenegildo and Bujuru beaches, (b) the landward dune transgression, and (c) a 1-meter depth terrace bordering the Patos lagoon, interpreted as a drowned lagoonal margin. The authors suggest that sea level started to rise 1-2 ka ago, when it probably was 1-2 m lower than the present level.
Lagoonal muds exposed at the backshore are a strong evidence of coastline retreat. However, the stratigraphy of transgressive barriers migrating landwards due to a sea level rise, clearly shows that, after barrier translation, lagoonal/estuarine sediments may outcrop somewhere at the shoreface or even at the continental shelf, but not at the backshore (see Kraft 1971, Morton 1995, Roy et al. 1994) (Fig. 4a). The outcrop of lagoonal sediments at the backshore typically occurs on barriers that are translating landwards mainly controlled by a negative balance on sediment budget during a relatively stable sea level condition. A shift from a sea level rise to a negative balance on sediment budget as the main factor controlling barrier transgression may lead to such stratigraphic record where lagoonal muds outcrop at the backshore or even at the foreshore on a microtidal barrier (Dillenburg et al. 2004a) (Fig. 4b and c).

The hypothesis of a rising sea level inducing landward dune transgression was first presented by Cooper (1958) while studying dune fields in Oregon (USA). Since then, opposite ideas have suggested that dunes transgression may be facilitated by the exposure of shelf sands under a sea level fall (e.g. Dominguez et al. 1987). According to Hesp and Thom (1990), transgressive dunes can be activated either by changes in external boundary conditions (e.g. sea level change) or by internal morphodynamic adjustments, being difficult to define which one is the effective cause.

Finally, the 1-meter deep terrace bordering the Patos lagoon is a product of lagoonal margin progradation (Barboza, personal communication) rather than a margin drowned by a 1-2 m rise in sea level, as suggested by Tomazelli and Villwock (1989). New ${ }^{14} \mathrm{C}$ datings of shells from a $2.7-\mathrm{m}$ long core collected near the border and within the most conspicuous terrace showed ages of $240 \pm 80$ years and $310 \pm 60$ years for samples collected at 2.0 and $2.3-\mathrm{m}$ deep, respectively (Barboza, personal communication). These ages do not support the hypothesis of the terrace being a lagoonal margin older or even 


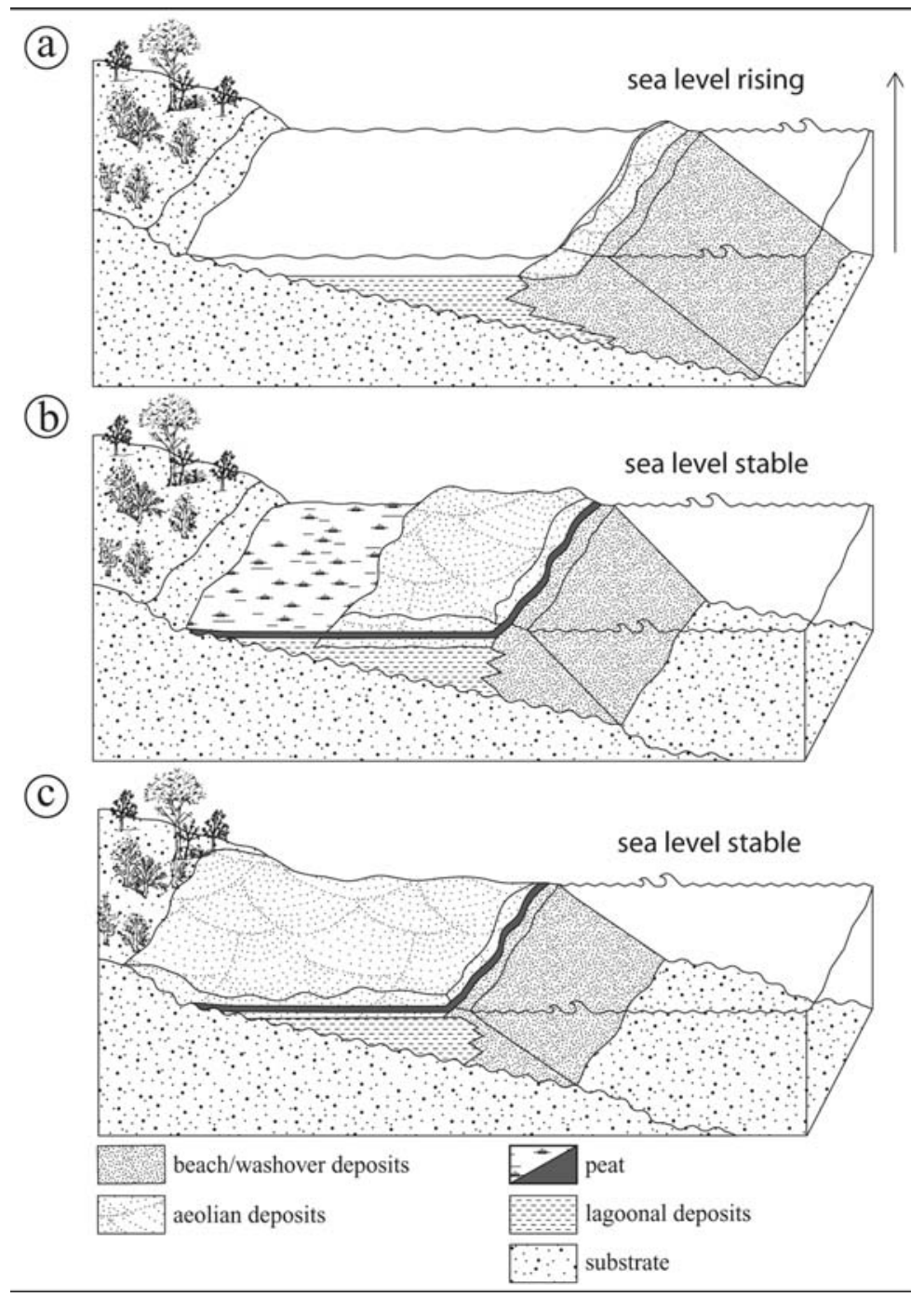

Fig. 4 - Barrier stratigraphy produced by a sea level rise (a typical transgressive barrier) showing the potential outcropping of lagoonal sediments at the shoreface or at the continental shelf (a), and a receded barrier translating landwards due to a negative balance on sediment budget, during a relatively stable sea level condition and showing the same general stratigraphy of a transgressive barrier, but with lagoonal sediments exposed close to sea level (b and c) (From Dillenburg et al. 2004a).

contemporaneous to the rise in sea level occurred at 1-2 ka ago, as suggested by Tomazelli and Villwock (1989). Additionally, three studies indicate a continuous sea level fall in the last $2 \mathrm{ka}$ with no evidences of levels below the present along the southern Brazilian coast (Martin et al. 1979, Angulo and Lessa 1997, Angulo et al. 1999).

\section{Coastal Sediment Budget}

Sediment budget is a major factor controlling shoreline changes. Sea level change is the key-factor determining large-scale coastal evolution when it rises or falls rapidly. However, when sea level is stable (or quasi-stable), temporal and spatial varia- 
tions in the sediment budget control barriers evolution (Roy et al. 1994). Generally, negative balances on sediment budget favors shoreline retreat, while positive balances favors progradation.

The RS coast presents two large lagoons along the central (Patos lagoon) and southern coastal sectors (Mirim lagoon) and several other small lagoons and lakes along the northern littoral. This lagoon system traps sediment from fluvial discharge, reducing significantly the sand volume reaching the shore (Tomazelli et al. 1998). Such condition exists since the formation of Barrier IV, so inland sources have not contributed to coastal sediment budget at least in the last $5 \mathrm{ka}$. Alongshore gradients of wave energy regulate the sand budget in the RS coast (Dillenburg et al. 2003). Large-scale gentle coastal projections concentrate wave energy while it is dissipated in the gentle shelf gradients adjacent to coastal reentrances. The latter has favored high rates of onshore sand transfer inducing coastal progradation in a long-term (Dillenburg et al. 2000). Thus, a link between coastal morphology, wave energy gradients, and imbalances on sand budget is evident. Changes in coastal sediment budget in RS will be discussed below in terms of long and short temporal and spatial scales.

\section{LONG SCALE}

Long-term changes on coastal sediment budget will be discussed here as the influence of a macro-scale shoreline configuration and shelf morphology on the alongshore distribution of wave energy that has strongly controlled coastal evolution in Rio Grande do Sul (Dillenburg et al. 2000).

At the end of the Post-Glacial Marine Transgression (5 ka) the contour of the RS coast was similar to the present one, which is gently undulated, alternating gentle reentrances and projections (Fig. 1). Since then, barriers prograded within coastal reentrances and retreated mainly along the southern half of coastal projections. This contrasting behavior could not be explained by sea level changes alone what would favor either progradation or retrograda- tion under a falling or rising condition, respectively. In fact, sea level has remained stable or felt very slowly (about 2-4 m) in the last $5 \mathrm{ka}$, showing minor interference on coastal evolution. The depositional and erosional behavior of coastal reentrances and projections, respectively, has been explained by May and Tanner (1973) using a graphical model for littoral sediment transport. In general terms, the model explains how the coastline tends to flatten out its embayments and projections by wave action. Due to refraction, wave energy concentrates along coastal projections while it is dispersed along the reentrances. As a result, coastal projections erode and the sediments are transported alongshore to be deposited in adjacent embayments. Wave energy is enhanced along coastal projections also due to the steeper adjacent shelf morphology that dissipates less energy by bottom friction (Wright 1974). As long-term coastal erosion in Rio Grande do Sul is restricted to protruding (steeper) sections of the coast, it is believed that negative balances on sediment budget due to wave energy concentration is an important factor driving barrier retrogradation.

Considering that shoreline orientation and direction of prevailing winds may have remained the same throughout the Holocene to the present, the angle waves approach to the shoreline is a factor that might have significant influence on both the longand short-time scale. Lima et al. (2001) have estimated the potential littoral drift along the RS coast based on wave measurements in deep water applying the Energy Flux Method (USACE 1984). Their results show that higher potential of alongshore sediment transport is estimated to occur along the southern half of coastal projections (where shoreline orientation is about $\mathrm{N} 45^{\circ} \mathrm{E}$ ), where intense coastal erosion is usually observed. Thus, shoreline orientation also plays an important role on the littoral drift and coastal erosion along the RS.

\section{Short Scale}

Short scale variations on sediment budget are related to natural and human-induced coastal pro- 
cesses, such as offshore sand transport during storm surges, concentration of wave energy due to submerged small-scale features, and human activities.

\section{Storm Surges}

Storm surges occur when the passage of a coastal storm induces water levels to exceed the predicted tide (Dolan and Davis 1994). In southern Brazil, they occur when S-SE winds pile water onshore during the passage of intense cold fronts. Storm surges are about $1.5-\mathrm{m}$ high along the RS coast, where the higher water level intensify the erosive capacity of storm waves, causing severe damage at the coast mainly when simultaneous with high spring tides (Calliari et al. 1998b). This catastrophic combination is more frequent in April and May and is more destructive as it lasts longer (Calliari et al. 1998b). It is also known that the frequency of storms is also a factor that influences beach erosion (Fenster et al. 2001).

Studies addressing the occurrence and impact of storm surges in Brazil are scarce and limited to the monitoring of individual events. Few examples are the storms of July 14, 1993 and April 19-21, 1995 (Calliari et al. 1998b), April 3-5 and 24-26, 1997 (Barletta and Calliari 2003), and April 16, 1999 (Esteves et al. 2003a). The 1993 and the 1999 storms were very similar and consisted in extratropical cyclones formed after the passage of a cold front striking the RS coast with average wind velocities of about $75 \mathrm{~km} / \mathrm{h}$, resulting in a storm surge of $1.3 \mathrm{~m}$ and $0.8 \mathrm{~m}$ (measured at the Rio Grande Port), respectively (Esteves et al. 2000). Beach profile measurements showed that the 1993 and 1999 storms caused subaerial beach erosion in Hermenegildo of $60 \mathrm{~m}^{3} / \mathrm{m}$ and $45 \mathrm{~m}^{3} / \mathrm{m}$, respectively. Tozzi and Calliari (2000) observed that maximum changes in sand volume occur when the first fall storms (from March to June) erode the accreted profile built during the summer months (from December to March). Based on the results of Tozzi (personal communication), Esteves et al. (2000) stated that the storm of April 1999 was a typical example of the high-energy events that threat Hermenegildo once a year. The number of cold fronts passages along the RS coast in the winter months (June to August) from 1988 to 1998 varied from 6 to 14, with a mean of 10 for that period (Britto and Saraiva, personal communication). However, it is still lacking studies that show storms distribution and frequency, related storm surges, and beach profile responses in a longer term (do they fully recover?).

\section{Concentration of Wave Energy Due to Submerged Small-Scale Features}

Recent studies have shown that convergence of wave rays due to refraction on small-scale changes in bathymetry concentrates wave energy at some coastal sectors and is one of the probable causes of erosion in Rio Grande do Sul (Calliari et al. 1998a, Speranski and Calliari 2001). According to these studies, convergence patterns in those two areas were identified for waves with period longer than $9 \mathrm{~s}$ approaching from SSE-SW while a divergent pattern is observed in the northern shores. Speranski and Calliari (2001) suggest that wave "focus" is the major cause of erosion in the Conceição lighthouse area and in Hermenegildo. The authors have stated that most of the Rio Grande do Sul shoreline is stable as concentration of wave energy is not observed along most of the coast. However, this mechanism could not explain erosion in Lagamarzinho, where Barletta and Calliari (2003) have estimated a retreat rate of $1 \mathrm{~m} / \mathrm{yr}$. Based on Calliari et al. (2003) data, Esteves et al. (2002) estimated that wave refraction may explain erosion along about $15 \%$ of the RS coast, accretion along $2 \%$, and a variable response along $8 \%$ of the RS shoreline. These data do not imply that the remaining of the shoreline is stable, as other factors clearly contribute to changes in RS shorelines.

\section{Human Activities}

Despite the long and undeveloped coastal segments, almost one-third of the state shoreline have been impacted by human activities, such as urbanization in 
active dune areas, shore armoring, sand mining, and construction of jetties (Esteves et al. 2000). Anthropogenic activities affect local sand balance, more in a way of intensifying natural shoreline changes rather than generating them. For example, fixation of the Patos lagoon inlet by two 4-km long jetties accelerated accretion on updrift (southern) beaches due to obstruction of the longshore sediment transport, an area that was already prograding in the longterm (Dillenburg et al. 2000). In Hermenegildo, urbanization in the active beach/dune system and coastal armoring seem to have aggravated erosion in a long-term retreating shoreline. Coastal development did not leave much space for natural beach dynamics to take place increasing the risk of structures damage during storms (e.g. Tramandaí and Hermenegildo). The artificial closure of natural washouts might be another anthropogenic change that tampers with local sand balance. In many coastal communities, washouts were artificially closed for road construction and tend to reopen temporarily during intense rainfall events. Sand from the dune/beach system has been used for landfill and civil engineering purposes for a long time and, in some places, resulted in the complete removal of dunes. Although the impact of human activities in the sand balance is still unknown, it seems to play a role only in a local extent, enhancing natural trends rather than reversing them (Esteves et al. 2002).

\section{SUMMARY}

Sandy barriers dominate the scenario along the 620$\mathrm{km}$ long Rio Grande do Sul coastline. The type and evolution of these barriers during the last $5 \mathrm{ka}$ clearly indicate that sea level oscillations were not the main factor controlling coastal evolution during the Late Holocene. If that was the case, coastal barriers would have evolved in a more uniform way.

Because minor or no sand is delivered by streams to the coastal system in the last $5 \mathrm{ka}$, sediment budget imbalances might have resulted from alongshore gradients of wave energy. Negative balances on sediment budget were produced by con- centration and enhancing of wave energy that are the main factors driving the retrogradation of barriers along coastal projections. In the other hand, dispersion and reduction of wave energy resulted in positive balances on the sediment budget, favoring barrier progradation along coastal embayments. Extensive exhumation of lagoonal muds along the southern half of coastal projections (e.g. Bujuru and Hermenegildo), where shoreline orientation is $\mathrm{N} 45^{\circ} \mathrm{E}$, suggests that the appropriate angle of wave attack plays an important role on coastal erosion. As pointed out by Lima et al. (2001), the highest rates of littoral drift occur along this shoreline's orientation. Therefore, there are evidences that erosion along the RS shoreline is the continuity of a largescale geological evolution operating in the last $5 \mathrm{ka}$; with erosion being more intense along the southern half of gentle coastal projections.

The focusing of wave energy due to refraction on small-scale submerged features, suggested by Calliari et al. (1998a) as the major cause of erosion in the Conceição lighthouse and Hermenegildo, sounds reasonable to explain local erosion. However, this process cannot explain the widespread long-term erosion along most of the central RS coast, from Estreito to Lagamarzinho (Fig. 5). If erosion in Conceição lighthouse and Hermenegildo was due to wave refraction on small-scale features only, the shoreline should be locally reentrant, what is not the case.

The short-term erosion detected from the analysis of 1997 and 2000 shorelines (mapped by DGPS) and a coastal chart of 1975 should be viewed cautiously. If erosion is really affecting approximately $80 \%$ of the coast of Rio Grande do Sul (Toldo et al. 1999, Esteves et al. 2002) a new explanation should be formulated. The results presented by both authors show a high frequency alternation of coastal stretches under erosion, accretion, and stable. Such behavior means that coastal processes are changing continuously along the coast and/or their relative dominance changes alongshore. If, in the future, these results become more consistent with longer historical data (a decade or more) new factors driv- 


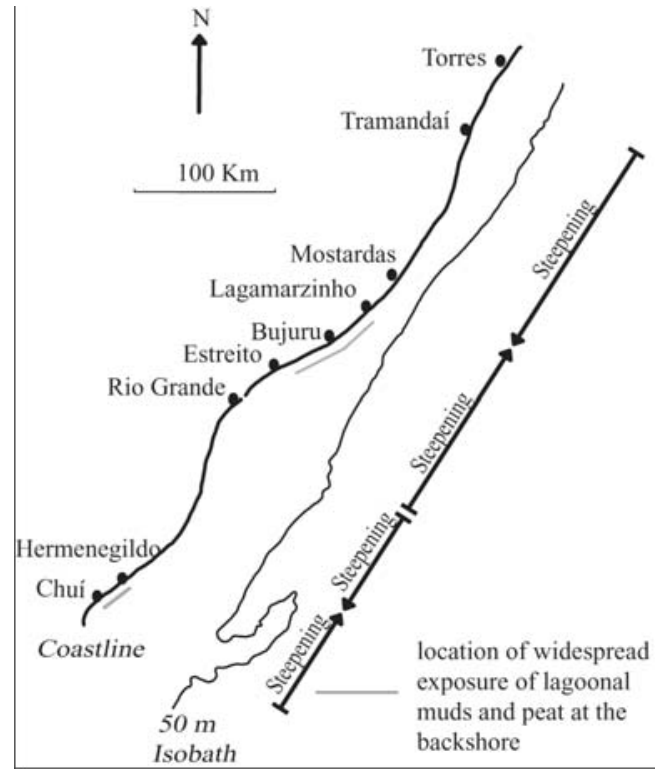

Fig. 5 - Coastline of Rio Grande do Sul showing the location of widespread exposure of lagoonal muds and peat at the southern half of protruding (steeper) sections of the coast.

ing shoreline behavior should be investigated (e.g. cell circulation controlled by submerged features in the shoreface or inner shelf). The impact of human activities in the sand balance is still unknown, but seems to play a role only in a local extent.

\section{RESUMO}

Evidências de erosão costeira no Rio Grande do Sul têm sido obtidas através de três métodos: (a) análises estratigráficas e morfodinâmicas de longo período de barreiras costeiras, (b) mapeamento anual da linha de costa através do Sistema de Posicionamento Global Diferencial (DGPS), e (c) levantamentos altimétricos de perfis praiais. $\mathrm{O}$ primeiro método mostra a erosão costeira como uma continuidade da evolução geológica nos últimos $5 \mathrm{ka}$, e ocorrendo principalmente na metade sul de suaves projeções costeiras. O segundo método representa uma escala temporal curta e indica que, aproximadamente $80 \%$ da costa está em erosão. Levantamentos altimétricos de perfis praiais têm sido executados em poucos locais, distantes uns dos outros, desde o início dos anos 1990; e, consequientemente, seus resultados refletem um comportamento local e de curto período da linha de costa. A avaliação crítica dos dados até hoje publicados sobre a erosão da linha de costa do Rio Grande do Sul sugere fortemente que o balanço negativo no estoque de sedimentos costeiros, em escalas de longo e curto período, é a principal causa da erosão.

Palavras-chave: evolução costeira, Quaternário, mudanças da linha de praia, barreiras costeiras, estoque de sedimentos.

\section{REFERENCES}

Angulo RJ and Lessa GC. 1997. The Brazilian sea level curves: a critical review with emphasis on the curves from Paranaguá and Cananéia regions. Mar Geol 140: 141-166.

Angulo RJ, Giannini PCF, Suguio K and Pessenda LCR. 1999. Relative sea level changes in the last 5500 years in southern Brazil (Laguna-Imbituba region, Santa Catarina State) based on vermetid ${ }^{14} \mathrm{C}$ ages. Mar Geol 159: 323-339.

Barletta RC and Calliari LJ. 2003. An assesment of the atmospheric and wave aspects determining beach morphodynamic characteristics along the central coast of RS State, southern Brazil. J Coast Res SI 35: 300-308.

BIRD ECF. 1985. Coastline Changes. London: John Wiley \& Sons, $219 \mathrm{p}$.

Calliari LJ, Speranski N and Boukareva I. 1998a. Stable focus of wave rays as a reason of local erosion at the southern Brazilian coast. J Coast Res SI 26: 19-23.

Calliari LJ, Tozzi HAM and Klein AHF. 1998b. Beach morphology and coastline erosion associated with storm surges in southern Brazil - Rio Grande to Chuí, RS. An Acad Bras Cienc 70: 231-247.

Calliari LJ, Boukareva I, Pimenta F and SperanSKI N. 2003. Classification of the southern brazilian coast according to storm wave patterns and geomorphologic evidence of coastal erosion. J Coast Res SI 35: 339-342.

COOPER WS. 1958. Coastal sand dunes of Oregon and Washington. Geol Soc Am Mem 72, p. 169.

CORRÊA ICS. 1995. Les variations du niveau de la mer durant les derniers 17.500 ans BP: l'exemple de la plateforme continentale du Rio Grande do Sul-Brésil. Mar Geol 130: 163-178. 
Dillenburg SR. 1996. Oscilações Holocênicas do Nível Relativo do Mar Registradas na Sucessão de Fácies Lagunares na Região da Laguna de Tramandaí, RS. Pesquisas em Geociências 23: 17-24.

Dillenburg SR, Roy PS, Cowell PJ And Tomazelli LJ. 2000. Influence of antecedent topography on coastal evolution as tested by the Shorface Translation-Barrier Model (STM). J Coast Res 16: 71-81.

Dillenburg SR, Tomazelli LJ and Clerot LCP. 2003. Gradients of wave energy as the main factor controlling the evolution of the coast of Rio Grande do Sul in southern Brazil during the Late Holocene. In: Coastal Sediments '03, 5, Clearwater Beach. Proceedings ..., CD Rom, Regional alongshore variability of shoreline movements.pdf, $9 \mathrm{p}$.

Dillenburg SR, Tomazelli LJ and Barboza EG. 2004a. Barrier evolution and placer formation at Bujuru southern Brazil. Mar Geol 203: 43-56.

Dillenburg SR, Tomazelli LJ, Hesp PA, Barboza EG, Clerot LCP and Silva DB. 2004b. Stratigraphy and evolution of a prograded transgressive dunefield barrier in southern Brazil. J Coast Res SI, in press.

Dolan R AND Davis RE. 1994. Coastal Storm Hazards. J Coast Res SI 12: 103-114.

Dominguez JML, Martin L and BitTencourt ACSP. 1987. Sea level History and Quaternary Evolution of River Mouth-Associated Beachridge Plains Along the East-Southeast Brazilian coast: A Summary. In: Nummedal D et al. (Ed.), Sea level Fluctuations and Coastal Evolution. Tulsa: The Society of Economic Paleontologists and Mineralogists, Special Publication 41, p. 116-127.

Esteves LS, Pivel MAG, Silva ARP, Barletta RC, VRanjac MP, Oliveira UR and Vanz A. 2000. Beachfront owners perception of erosion along an armored shoreline in southern Brazil. Pesquisas em Geociências 27: 97-109.

Esteves LS, Toldo Jr. EE, Dillenburg SR and TomAZELLI LJ. 2002. Long- and Short-Term Coastal Erosion in Southern Brazil. J Coast Res SI 36: 273-282.

Esteves LS, Oliveira UR, Silva ARP, Vranjac MP, Pivel MAG, Vanz A and Barletta RC. 2003a. Seasonal changes in beach profile inducing the response of beachfront owners in southern Brazil. J Coast Res SI 35: 557-563.
Esteves LS, Silva ARP, Arejano TB, Pivel MAG And VRAnJaC MP. 2003b. Coastal development and human impacts along the Rio Grande do Sul beaches, Brazil. J Coast Res SI 35: 548-556.

Esteves LS, Dillenburg SR And Toldo Jr. EE. 2003c. Regional alongshore variability of shoreline movements in southern Brazil. In: Coastal Sediments '03, 5, Clearwater Beach. Proceedings ..., CD Rom, Regional alongshore variability of shoreline movements.pdf, $11 \mathrm{p}$.

Fenster MS, Dolan R and Morton RA. 2001. Coastal storms and shoreline change: signal or noise. J Coast Res 17: 714-720.

Fontana RL. 1990. Investigações Geofísicas Preliminares sobre o Cone do Rio Grande, Bacia de Pelotas - Brasil. Acta Geol Leopold 30(13): 161-170, (Publicação Especial 6).

Hesp PA AND Thom BG. 1990. Geomorphology and evolution of erosional dunefields. In: NORDSTROM KF et al. (Ed.), Coastal Dunes: process and morphology, Chichester: J. Wiley \& Sons, p. 253-288.

KrAfT JK. 1971. Sedimentary Facies Patterns and Geologic History of a Holocene Marine Transgression. Geol Soc Am Bull 82: 2131-2158.

Lima SF, Almeida LESB and Toldo JR. EE. 2001. Estimativa da capacidade do transporte longitudinal de sedimentos a partir de dados de ondas para a costa do Rio Grande do Sul. Pesquisas em Geociências 28: 99-107.

Martin L, Suguio K And Flexor JM. 1979. Le Quaternaire marin du littoral brésilien entre Cananéia (SP) et Barra de Guaratiba (RJ). In: INTERNATIONAL SYMPOSIUM ON COASTAL EVOLUTION IN THE QUATERNARY, São Paulo. Proceedings ..., São Paulo: EDUSP, 1979, p. 296-331.

May JP And TANner WF. 1973. The littoral power gradient and shoreline changes. In: COATES DR (Ed.), Publications in Geomorphology, Binghamton: State University of New York, p. 43-60.

Morton RA. 1995. Texas Barriers. In: DAvis JR. RA (Ed.), Geology of Holocene Barrier Island Systems, Germany: Springer-Verlag, p. 75-114.

Morton RA, Leach MP, Paine JG and Cardoza MA. 1993. Monitoring beach changes using GPS surveying techniques. J Coast Res 9: 702-720. 
Motta VF. 1969. Relatório Diagnóstico Sobre a Melhoria e o Aprofundamento do Acesso pela Barra do Rio Grande. Porto Alegre, UFGRS, Instituto de Pesquisas Hidráulicas, 144 p.

Roy PS, Cowell PJ, Ferland MA and Thom BG. 1994. Wave Dominated Coasts. In: CARTER RWG AND Woodroffe CD (Ed.), Coastal Evolution, Late Quaternary Shoreline Morphodynamics, Cambridge: Cambridge University Press, p. 121-186.

Speranski N and Calliari LJ. 2001. Bathymetric lens and localized coastal erosion in southern Brazil. J Coast Res SI 34: 209-215.

Toldo Jr. EE, Dillenburg SR, Almeida LES, TabAJara LL, Martins RR and Cunha LOBC. 1993. Parâmetros Morfodinâmicos da Praia de Imbé, RS. Pesquisas em Geociências 20: 27-32.

Toldo Jr. EE, Almeida LES, Barros C and Martins LR. 1999. Retreat of the Rio Grande do Sul Coastal Zone, Brazil. In: Martins LR and Santana CI (Ed.), Non Living Resources of the Southern Brazilian Coastal Zone and Continental Margin. Porto Alegre, Brazil: Editora da UFRGS, p.62-68.

Tomazelli LJ and Dillenburg SR. 1998. O uso do registro geológico e geomorfológico na avaliação da erosão de longo prazo na costa do Rio Grande do Sul. Geosul 14: 47-53.

Tomazelli LJ and Villwock JA. 1989. Processos erosivos atuais na costa do Rio Grande do Sul, Brasil: evidências de uma provável tendência contemporânea de elevação do nível relativo do mar. In: CoNGRESSO DA AbEQUA, II, Rio de Janeiro, Brasil. Boletim de Resumos..., p.16.

Tomazelli LJ and Villwock JA. 1992. Considerações Sobre o Ambiente Praial e a Deriva Litorânea de Sedimentos ao Longo do Litoral Norte do Rio Grande do Sul, Brasil. Pesquisas em Geociências 19: 3-12.
Tomazelli LJ, Villwock JA, Dillenburg SR, Bachi FA AND Dehnhardt BA. 1998. Significance of present-day coastal erosion and marine transgression, Rio Grande do Sul, southern Brazil. An Acad Bras Cienc 70: 221-229.

Tomazelli LJ, Dillenburg SR and Villwock JA. 2000. Late Quaternary geological history of Rio Grande do Sul coastal plain, southern Brazil. Rev Bras Geoc 30: 470-472.

Tozzi HAM and Calliari LJ. 2000. Morfodinâmica da Praia do Cassino, RS (Cassino Beach Morphodynamics, RS - Brasil). Pesquisas em Geociências 27: $29-42$.

USACE (US ARmy CoRps of ENGINEERs). 1984. Shore Protection Manual (2nd edition). Washington, DC: U.S. Government Printing Office, variously paginated.

Villwock JA AND Tomazelli LJ. 1995. Geologia Costeira do Rio Grande do Sul. Notas Técnicas 8: 1-45.

Villwock JA, Tomazelli LJ, Loss EL, DehnhardT EA, Horn Fo. NO, Bachi FA and Dehnhardt BA. 1986. Geology of the Rio Grande do Sul coastal province. In: RABASSA J. (Ed.), Quaternary of South America and Antartic Peninsula, vol. 2, Rotterdam: A.A. Balkema, p. 79-97.

WRIGHT LD. 1974. Nearshore wave-power dissipation and the coastal energy regime of the Sydney-Jervis Bay region, New South Wales: A comparison. Australian J Mar Fresh Res 27: 633-640. 